DOI 10.31558/2307-2318.2021.4.14

УДК 336.2

JEL: H61, H72, H79

Волкова В.В.,

кандидат економічних наук, доцент, доцент кафедри фінансів і банківської справи, Донецький національний університет імені Василя Стуса

ORCID ID: 0000-0003-1539-6194

v.volkova@donnu.edu.ua

Волкова Н.І.,

кандидат економічних наук, доцент, доцент кафедри фінансів і банківської справи, Донецький національний університет імені Василя Стуса

ORCID ID: 0000-0003-3790-3636

n.volkova@donnu.edu.ua

\title{
ОРГАНІЗАЦІЙНО-ЕКОНОМІЧНІ ЗАСАДИ РОЗВИТКУ МІСЦЕВИХ БЮДЖЕТІВ В УМОВАХ РЕФОРМУВАННЯ МІСЦЕВОГО САМОВРЯДУВАННЯ (НА ПРИКЛАДІ ВІННИЦЬКОЇ МІСЬКОЇ ТЕРИТОРІАЛЬНОЇ ГРОМАДИ)
}

В статті обтрунтовано вплив реформи місцевого самоврядування на економічний розвиток територіальних громад. Зроблено акиент на тому, щзо місцеві бюджети виступають основним джерелом фінансових ресурсів, які необхідні органам місиевого самоврядування для виконання покладених на них функиій. Проаналізовано динаміку формування об'єднаних територіальних громад за 2016-2020рр. Зазначено вплив пандемії COVID-19 на розвиток місиевих бюджетів. Наведено схему економічного взаємозв'язків місиевого бюджету та рівня життя населення територіальної громади та виділено основні проблеми їх формування. Проаналізовано динаміку та структуру доходів і видатків бюджету Вінницької міської об'єднаної територіальної громади за 2016-2020рр. Виокремлено завдання покращення розвитку територіальної громади, щзо треба реалізовувати на державному та місиевому рівнях. Запропоновано механізм вдосконалення розвитку місцевих бюджетів, який дасть можливість більш раціонально використовувати кошти місиевих бюджетів за рахунок посилення конкурентних переваг територіальної громади та активізації інвестииійної діяльності. Обгрунтовано напрями розвитку територіальних громад на середньострокову перспективу в Украӥні.

Ключові слова: місчевий бюджет, місчеве самоврядування, територіальна громада, децентралізація, субсидіарність, рівень життя населення, інвестиційний клімат, економічний розвиток.

Рис. -5 , Таб. -1 , Літ. -9.

Постановка проблеми. Розвиток ефективного місцевого самоврядування, забезпечення стійкого та комплексного розвитку територій виступає одним 3 найважливіших завдань держави. Саме тому доцільно продовжувати роботу в напрямку забезпечення місцевих бюджетів відповідною фінансовою базою, оскільки наявність достатніх фінансових ресурсів для конкретної територіальної громади - гарантія іï 
успішного розвитку. Місцеві фінанси і місцеві бюджети стають основними фінансовими гарантами існування та розвитку демократії, надання населенню суспільних послуг і благ. Все це зумовлює актуальність обраної теми дослідження.

Аналіз останніх джерел та публікацій. Значний вклад у дослідження даної наукової проблеми внесли вітчизняні та зарубіжні вчені: Волохова І.С. [1]; Демиденко Л.М. [2]; Набатова Ю.О. [3]; Пальчук В. [4]. Проте, питання розробки пропозицій щодо зміцнення дохідної частини місцевих бюджетів в умовах децентралізації влади в Україні досліджено недостатньо.

Мета дослідження полягає в наданні пропозицій щодо вдосконалення розвитку місцевих бюджетів в умовах реформування місцевого самоврядування в Україні.

Виклад основного матеріалу дослідження. Реформа місцевого самоврядування в Україні грунтується на засадах децентралізації та передбачає: реалізацію певних кроків забезпечення бюджетної автономії і фінансової самостійності територіальних громад; формування їх інституційної та фінансової спроможності; забезпечення видаткових повноважень 3 чітким розподілом компетенцій на принципах субсидіарності; формування нової системи міжбюджетного вирівнювання та надання трансфертів; посилення відповідальності за реалізацію державної політики у різних галузях профільними міністерствами; визначення стабільних джерел доходів місцевих бюджетів [5].

Реформа децентралізації надала громадам можливості для забезпечення та зміцнення економічної бази місцевого розвитку через отримані ресурси та фінанси. На новоутворення покладено власні та делеговані повноваження, спрямовані на вирішення питань місцевого розвитку. Одним із основних повноважень органів місцевого самоврядування є забезпечення місцевого економічного розвитку. Економічна основа діяльності об'єднаних територіальних громад (далі - ОТГ) складається з: 1) місцевого бюджету; 2) трансфертів 3 державного бюджету; 3) коштів Державного фонду регіонального розвитку, як фінансової підтримки у вигляді субвенції; 4) коштів Європейського Союзу за Програмою підтримки секторальної політики в Україні [6].

При цьому місцеві бюджети вважаються основним джерелом фінансових ресурсів, необхідних органам місцевого самоврядування для виконання покладених на них функцій відповідно до чинного в державі розподілу повноважень між рівнями i гілками влади. Місцеві бюджети відіграють важливу роль в соціально-економічному житті країни, виступають фінансовою базою місцевого самоврядування, без них не зможе повною мірою функціонувати демократична держава. Також за допомогою місцевих бюджетів розподіляються та використовуються грошові фонди між галузями народного господарства. Крім того, місцевий бюджет контролює фінансовогосподарську діяльність підприємств та організацій, що $є$ підвідомчими органам місцевого самоврядування.

Місцеві бюджети являють собою фінансовий план формування та використання грошових коштів місцевого самоврядування. Поняття місцеві бюджети доцільно розглядати в двох аспектах: як організаційну форму мобілізації частини фінансових ресурсів в розпорядження місцевих органів самоврядування та як систему фінансових відносин, які виникають між місцевими бюджетами.

На нашу думку, до фінансів органів місцевого самоврядування відносяться місцеві бюджети, місцеві позики та фінанси органів самоорганізації населення, створені на місцевому рівні. Відповідно до фінансів органів регіонального самоврядування відносяться ті ж складові, але існуючі на регіональному рівні. 
Територіальні фінанси охоплюють місцеві та регіональні фінанси і входять до складу публічних (суспільних) фінансів. В Україні, як правило, не поділяють територіальні фінанси на місцеві та регіональні. Загальну сукупність розглядають як місцеві фінанси. Вважаємо, цей поділ є доцільним. Місцеві фінанси охоплюють фінанси первинних природних територіальних утворень будь-якої держави, регіональні - вторинних штучних. Функції, завдання та повноваження їхніх органів влади завжди різні, відрізняються своїм рівнем.

Сучасні вчені [7] наголошують, що децентралізація повноважень, ресурсів і відповідальності змусить місцеві органи влади працювати ефективніше. Крім того, в рамках концепції реформування місцевого самоврядування та територіальної організації влади в Україні, затвердженої розпорядженням Кабінету Міністрів України від 01.04.2014 р. № 333 передбачано створення законодавчої бази діяльності органів місцевого самоврядування та органів виконавчої влади на новій територіальній основі 3 визначенням повноважень та їх ресурсного забезпечення. Також в рамках іiі реалізації прийнято Закон України "Про добровільне об'єднання територіальних громад". У 2015 p. стартував процес об'єднання територіальних громад та створення спроможних об'єднаних громад. Процес створювання ОТГ називають динамічним (табл. 1).

Таблиця 1. Динаміка формування ОТГ за 2015-2020 pp.[7]

\begin{tabular}{|c|c|}
\hline Рік & Кількість ОТГ \\
\hline 2015 & 159 \\
\hline 2016 & 366 \\
\hline 2017 & 665 \\
\hline 2018 & 874 \\
\hline 2019 & 1009 \\
\hline 2020 & 1029 \\
\hline
\end{tabular}

Дослідження фінансової децентралізації в Україні показують нестачу кваліфікованої робочої сили для успіху децентралізації, що посилюється пандемією COVID-19 і їі впливом на розвиток місцевих бюджетів. За підсумками 2020 року надходження до загального фонду місцевих бюджетів України (без урахування міжбюджетних трансфертів) склали 290,1 млрд грн, що становить 99,0\% від затвердженого річного плану 3 урахуванням змін (293,2 млрд грн). У порівнянні 3 планом без урахування змін (який було визначено при затвердженні місцевих бюджетів - 291,1 млрд грн) рівень виконання становить 99,6\%. При формуванні місцевих бюджетів на 2020 рік обсяг видатків було затверджено в сумі 443,0 млрд грн (загальний та спеціальний фонди). Протягом року місцевими радами вносилися зміни до планових показників, і на кінець року плановий показник з урахуванням внесених протягом 2020 року змін склав 522,5 млрд грн, тобто на 17,9\% більше від початкового плану. Обсяг фактичних видатків місцевих бюджетів у 2020 році склав 478,1 млрд грн, що на 7,9\% більше від затвердженого планового показника. 3 державного бюджету додатково не виділялися кошти місцевим бюджетам на боротьбу з COVID-19, фінансування видатків здійснювалося за рахунок перерозподілу загальної суми коштів, що була запланована під час прийняття Державного бюджету на 2020 рік [8].

Відомо, що стійке економічне зростання території забезпечує розвиток місцевого самоврядування та місцевих бюджетів. Стан місцевих бюджетів, в свою чергу, відображається на розвитку суспільства в цілому, тому наявність проблеми 
місцевих бюджетів негативно впливає на діяльність всіх суб'єктів господарювання та якість життя населення певної територіальної громади (рис.1).

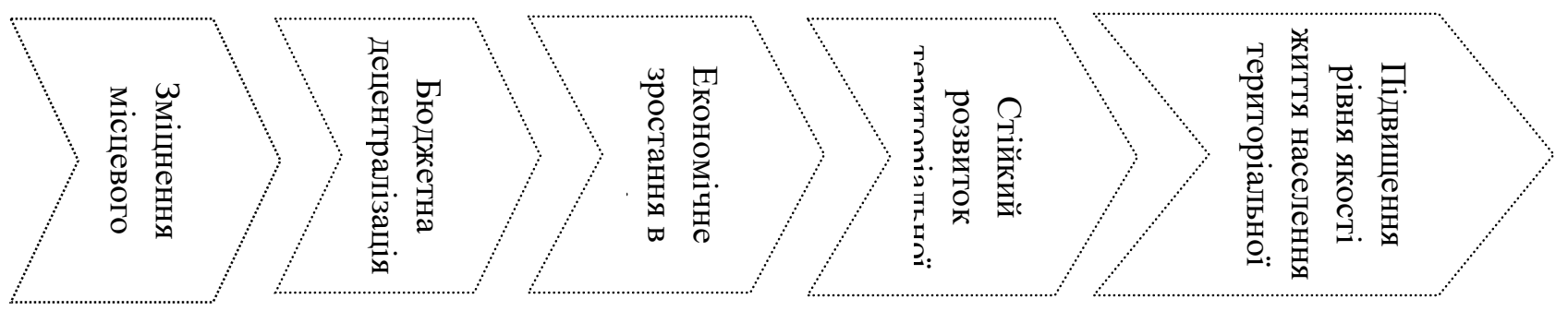

Рисунок 1 . Схема економічних взаємозв'язків місцевого бюджету та рівня життя населення територіальної громади*

*джерело: розроблено авторами бюджетів:

Дослідження довело, що на сьогодні існують наступні проблеми місцевих

- дефіцит доходів місцевого бюджету;

- слабка власна дохідна база;

- низька частка місцевих податків і зборів;

- високий рівень фінансової залежності місцевого бюджету від державного;

- безвідповідальність посадових осіб місцевого самоврядування.

Зазначимо, що особливої уваги потребують проблеми забезпечення місцевого самоврядування фінансовими ресурсами адекватними новим завданням, які стоять перед ними. Існує проблема формування місцевих бюджетів, адже основна частина їх доходів - трансферти, що свідчить про надмірну централізацію доходів місцевих бюджетів.

Динаміка доходів та видатків місцевого бюджету Вінницької міської територіальної громади предсталена на рисунку 2.

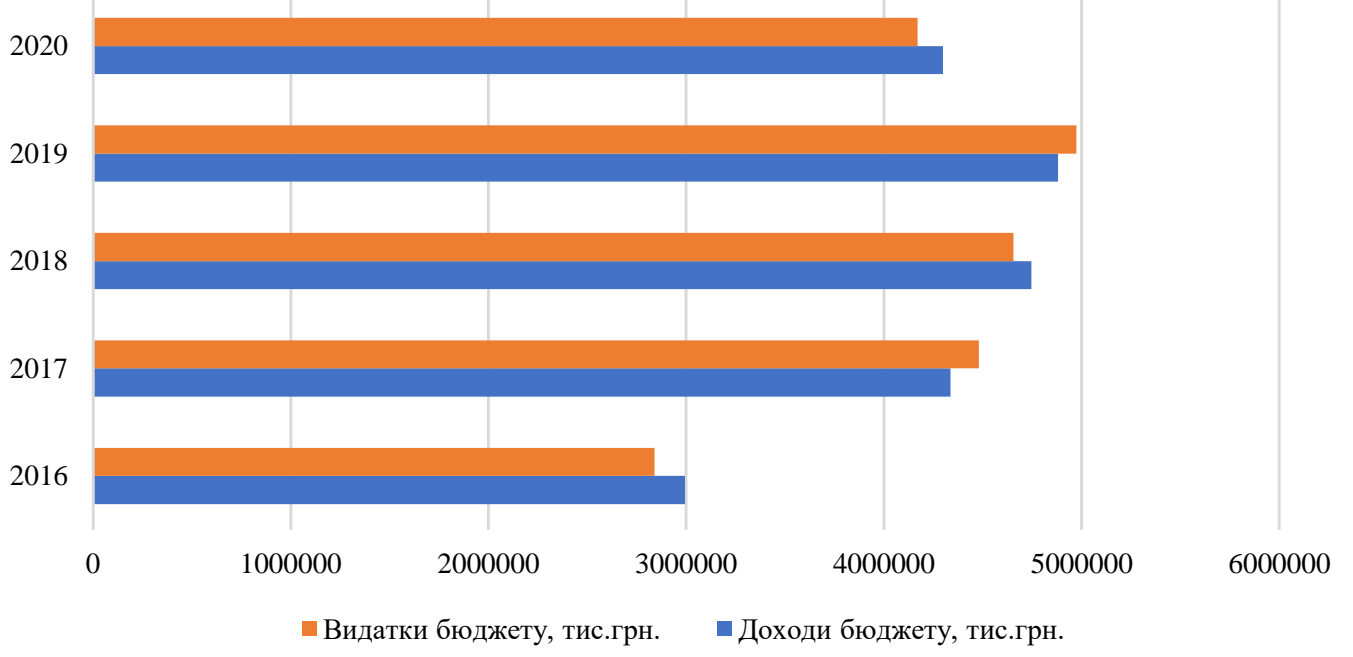

Рисунок 2. Динаміка доходів і видатків бюджету Вінницької міської територіальної громади за 2016-2020pp.*

*джерело: побудовано авторами за даними Вінницької міської Ради [9] 
Як видно 3 рисунку 2, динаміка доходів бюджету Вінницької міської територіальної громади протягом зазначеного періоду залишається позитивною. Але упродовж 2020-2021 рр. спостерігається незначне зменшення приросту доходів місцевих бюджетів, основною причиною чого є запроваджених карантинних заходів у зв'язку з пандемією COVID-19.

Далі наведемо структуру доходів до бюджету Вінницької міської територіальної громади за I квартал 2021 року (рис.3).

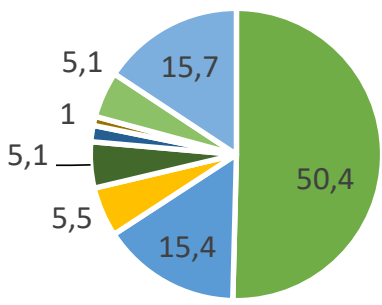

$$
\begin{aligned}
& \text { - ПДФО - Сдиний податок } \\
& \text { - Плата за землю Акцизний податок } \\
& \text { - Власні надходження бюджетних установ - Кошти від продажу землі } \\
& \text { - Інші доходи - Офіційні трансферти }
\end{aligned}
$$

Рисунок 3. Структура доходів бюджету Вінницької міської територіальної громади за 1 квартал 2021p.*

*джерело: побудовано авторами за даними Вінницької міської Ради [9]

Далі представимо структуру видатків бюджету Вінницької міської територіальної громади за I квартал 2021 року (рис.4).

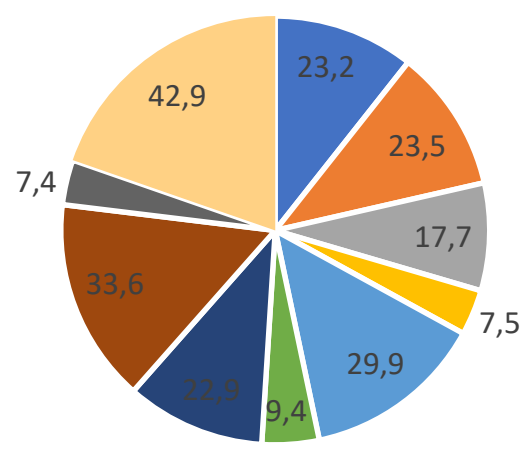

$$
\begin{array}{ll}
\text { - освіта } & \text { " соціальний захист та соціальне забезпечення } \\
\text { " культура і мистецтво } & \text { - будівництво та регіональний розвиток } \\
\text { " охорона здоровья } & \text { " житлово-комунальне господарство } \\
\text { - фізична культура і спорт } & \text { " транспорт і транспортна інфраструктура } \\
\text { - Зв'язок, телекомунікації та інформатика } & \text { - інші }
\end{array}
$$

Рисунок 4. Структура видатків бюджету Вінницької міської територіальної громади за 1 квартал 2021p.*

*джерело: побудовано авторами за даними Вінницької міської Ради [9] 
Підвищення ефективності управління місцевими фінансами насамперед залежить від ефективного функціонування органів місцевого самоврядування. Тому обгрунтуємо основні положення формування ефективної системи місцевого самоврядування, в основу якої має бути покладено створення сприятливих умов для переходу економіки регіону до повноцінних ринкових відносин, які стимулюють розвиток виробництва, наповнення ринку товарами, які найповніше задовольняють потреби громадян, що забезпечує гармонійний, соціально спрямований розвиток територій.

Вважаємо, що в процесі створення необхідних умов для розвитку територіальної громади повинні брати участь не тільки державні органи влади, але й органи місцевого самоврядування. Досягнення поставлених цілей розвитку стає можливим при об'єднанні зусиль всіх органів управління у виконанні завдань підвищення ефективності функціонування територій на основі ефективно функціонуючої системи місцевого самоврядування, що дає змогу підвищити рівень регіональної економіки і показники соціально - економічного розвитку країни в цілому. При цьому на державному рівні ключовими будуть такі завдання: 1) стимулювання діяльності органів місцевого самоврядування; 2) розширення напрямів для залучення фінансових ресурсів на територію адміністративних одиниць; 3) скасування існуючих організаційних обмежень; 4) удосконалення правового регулювання.

На рівні органів регіонального управління для створення умов щодо підвищення ефективності місцевого самоврядування необхідно вирішити такі питання, як: 1) зростання конкурентоспроможності на території адміністративної одиниці; 2) зниження рівня соціальної напруженості; 3) підвищення рівня довіри населення до органів місцевого самоврядування; 4) створення нових робочих місць; 5) зростання рівня інформатизації; 6) створення спеціальних рад з розвитку територій.

На рівні органів місцевого самоврядування доцільно виконати наступні завдання: 1) зростання якості послуг; 2) зниження ціни на соціальне обслуговування громадян; 3) розміщення коштів громадян в пріоритетних проєктах адміністративнотериторіальних одиниць; 4) підвищення поінформованості населення територій про діяльність органів місцевого самоврядування; 5) публікація річного фінансового звіту в засобах масової інформації; 6) публікація річного, щоквартального звітів про виконану роботу; 7) доведення інформації про цілі діяльності і завдання органів місцевого самоврядування до громадян.

Важливим в процесі удосконалення фінансування місцевих бюджетів в умовах реформування місцевого самоврядування $\epsilon$ створення організаційно-економічного механізму вдосконалення розвитку місцевих бюджетів (рис.5.).

Запропонований механізм дозволить більш раціонально споживати кошти місцевого бюджету за рахунок посилення конкурентних переваг територіальної громади та активізації інвестиційної діяльності.

Створення сприятливих умов для залучення інвестицій в реальний сектор економіки, застосування ринкових механізмів в використанні майна в комунальній власності, розвиток малого та середнього підприємництва сприятиме збільшенню доходів місцевих бюджетів. При цьому важелями покращення інвестиційного клімату можуть бути: доступність бюджетних кредитів, муніципальних гарантій та податкових пільг; залучення органів місцевого самоврядування до реалізації перспективних інвестиційних проектів за рахунок використання бюджетних джерел фінансування інвестицій та розміщення муніципальних позик; участь в інвестиційних програмах 
суб'єктів підприємництва шляхом використання муніципального приватного партнерства.

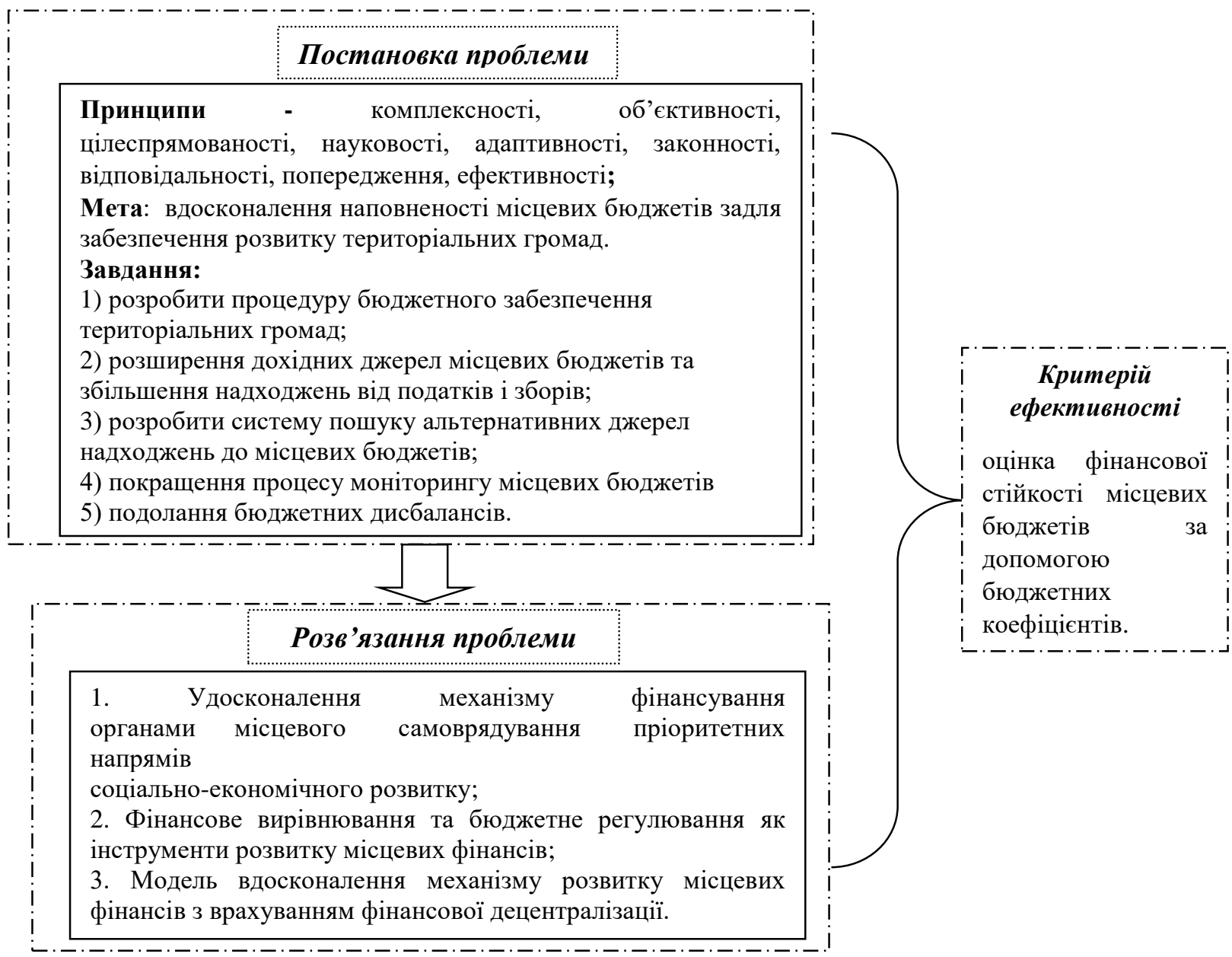

Рисунок 5. Організаційно-економічний механізм вдосконалення розвитку місцевих бюджетів*

*джерело: розроблено авторами

Доцільно також врахувати напрями розвитку територіальних громад на середньострокову перспективу в Україні:

- суспільні блага повинні надаватися тим рівнем самоврядування, який $\epsilon$ найближчим до споживача, що дасть можливість врахувати інтереси населення відповідних територій;

- потреба в суспільних благах повинна бути чітко обгрунтована з урахуванням можливості та доцільності їхнього надання приватним сектором економіки;

- доходи місцевого самоврядування мають бути максимально диверсифікованими;

- місцеве самоврядування повинно мати достатні податкові повноваження, щоб впливати на економічний розвиток власних територій;

- міжбюджетні трансферти повинні мати обмежений вплив на діяльність місцевого самоврядування;

- підприємства та бюджетні установи місцевого самоврядування повинні мати право на самостійну господарську діяльність, не залежну від рішень органів влади, а на підставі договірних відносин; 
- за можливості вільна конкуренція має бути рушійною силою розвитку комунальних підприємств та бюджетних установ;

- залучення інвестицій в реальний сектор економіки;

- в управління місцевими та регіональним фінансами максимально мають бути залучені мешканці територіальних громад.

Висновки і перспективи подальших досліджень. Таким чином, місцевий бюджет - це кошторис доходів і видатків фондів фінансових ресурсів, які формуються, розподіляються та перерозподіляються на рівні адміністративно-територіальних одиниць, затверджений відповідною радою.

Запропонований авторами організаційно-економічний механізм вдосконалення розвитку місцевих бюджетів сприятиме розвитку місцевих бюджетів за рахунок зміцнення конкурентних переваг відповідної територіальної громади в умовах децентралізації влади в Україні.

\section{СПИСОК ВИКОРИСТАНИХ ДЖЕРЕЛ}

1. Волохова, І.С. (2014). Місиеві фінанси та перспективи поглиблення фінансової децентралізації в Україні. Одеса: Атлант.

2. Демиденко, Л. М. (2015). Фіскальна децентралізація: німецький досвід та українські реалії. Вісник Київського Наџіонального університету імені Тараса Шевченка. Економіка, № 2(167), 49-54.

3. Набатова, Ю.О., Ус, Т.В. (2015). Формування місцевих бюджетів в умовах децентралізації фінансових ресурсів. Ефективна економіка, № 5 . < http://www.economy.nayka.com.ua/?op=1\&z=4100> (2021, червень, 25).

4. Пальчук, В. (2017). Місцеві бюджети в умовах фінансової децентралізації. Україна: подіï, факти, коментарі, № 6, 41-51. 〈http://nbuviap.gov.ua/images/ukraine/2017/ukr6.pdf> (2021, червень, 25).

5. Трансформація податкової системи України в умовах реформування місцевого самоврядування. <https://nu.edu.ua/wp-content/uploads/2021/04/aref galamai.pdf> (2021, червень, 26).

6. Сахно, Т.А. (2020). Економічне забезпечення діяльності об’єднаних територіальних громад. Бізнес-Інформ, 1, 135-142.

7. Ясинська, Н.А., Стурова, Є.О., Нетребенко, М.О. (2018). Результативність наповнення та використання місцевих бюджетів в умовах децентралізації влади в Україні. <http://www.economy.in.ua/pdf/4_2020/18.pdf> (2021, червень, 25).
8. Вплив
пандеміі
на
місцеві
фінанси.

$<$ https://decentralization.gov.ua/news/13503?page=7> (2021, серпень, 17).

9. Звіт про виконання бюджету Вінницької міської ОТГ. https://www.vmr.gov.ua/TransparentCity/Lists/BudjMista/ShowContent.aspx?ID=34 (2021, червень, 19).

\section{REFERENCES}

1. Volokhova, I.S. (2014). Local finances and prospects for deepening financial decentralization in Ukraine. Odessa: Atlant.

2. Demidenko, L.M. (2015). Fiscal decentralization: the German experience and Ukrainian realities. Bulletin of the Taras Shevchenko National University of Kyiv. Economics, № 2 (167), 49-54.

3. Nabatova, Yu.O., Us, T.V. (2015). Formation of local budgets in the conditions of decentralization of financial resources. Efficient Economy, № 5. Retrieved from http://www.economy.nayka.com.ua/?op=1\&z=4100. [in Ukrainian]. (2021, June, 25).

4. Palchuk, V. (2017). Local budgets in terms of financial decentralization. Ukraine: events, facts, comments, № 6, 41-51. Retrieved from http://nbuviap.gov.ua/images/ukraine/2017/ukr6.pdf. [in Ukrainian]. (2021, June, 25). 
5. Transformation of the tax system of Ukraine in the conditions of local self-government reform. Retrieved from https://lnu.edu.ua/wp-content/uploads/2021/04/aref_galamai.pdf [in Ukrainian]. (2021, June, 26).

6. Sakhno, T.A. (2020). Economic support for the activities of united territorial communities. Business Inform, 1, 135-142.

7. Yasinskaya, NA, Sturova, Ye.O., Netrebenko, MO (2018). Effectiveness of filling and using local budgets in the conditions of decentralization of power in Ukraine. Retrieved from http://www.economy.in.ua/pdf/4_2020/18.pdf [in Ukrainian]. (2021, June, 25).

8. The impact of the pandemic on local finances. Retrieved from https://decentralization.gov.ua/news/13503?page=7 [in Ukrainian]. (2021, August, 17).

9. Report on budget execution of Vinnytsia city OTG. Retrieved from https://www.vmr.gov.ua/TransparentCity/Lists/BudjMista/ShowContent.aspx?ID=34 [in Ukrainian]. (2021, June, 19).

\section{Волкова В.В., Волкова Н.И.}

ОРГАНИЗАЦИОННО-ЭКОНОМИЧЕСКИЕ ОСНОВЫ РАЗВИТИЯ МЕСТНЫХ БЮДЖЕТОВ В УСЛОВИЯХ РЕФОРМИРОВАНИЯ МЕСТНОГО САМОУПРАВЛЕНИЯ

(НА ПРИМЕРЕ ВИННИЦКОЙ ГОРОДСКОЙ ТЕРРИТОРИАЛЬНОЙ ОБЩИНЫ)

В статье обосновано влияние реформы местного самоуправления на экономическое развитие территориальных общин. Сделан акцент на том, что местные бюджеты выступают основным источником финансовых ресурсов, которые необходимы органам местного самоуправления для выполнения возложенных на них функций. Приведена динамика формирования объединенных территориальных общин за 2016-2020гг. Отмечено влияние пандемии COVID-19 на развитие местных бюджетов. Приведена схема экономических взаимосвязей местного бюджета и уровня жизни населения территориальной общины и выделены основные проблемы их формирования. Проанализирована динамика и структура доходов и расходов бюджета Винницкой городской объединенной территориальной общины за 2016-2020гг. Выделены задачи улучшения развития территориальной общины, которые целесообразно реализовывать на государственном и местном уровнях. Предложен механизм совершенствования развития местных бюджетов, который даст возможность более рационально использовать средства местных бюджетов за счет повышения конкурентных преимуществ территориальной общины и активизации инвестиционной деятельности. Обоснованы направления развития территориальных общин на среднесрочную перспективу в Украине.

Ключевые слова: местный бюджет, местное самоуправление, территориальная община, децентрализация, субсидиарность, уровень жизни населения, инвестиционный климат, экономическое развитие.

\section{V.Volkova, N.Volkova \\ ORGANIZATIONAL AND ECONOMIC FUNDAMENTALS OF LOCAL BUDGET DEVELOPMENT IN THE CONDITIONS OF LOCAL SELF- GOVERNMENT REFORM (ON THE EXAMPLE OF VINNITSA CITY TERRITORIAL COMMUNITY)}

The article substantiates the impact of local government reform on the economic development of territorial communities. Emphasis is placed on the fact that local budgets are the main source of financial resources needed by local governments to perform their functions. The dynamics of the formation of united territorial communities for 2016-2020 is given. The impact of the COVID-19 pandemic on the development of local budgets is noted. The scheme 
of economic interrelations of the local budget and a standard of living of the population of territorial community is resulted and the basic problems of their formation are allocated. The dynamics and structure of revenues and expenditures of the budget of the Vinnytsia city united territorial community for 2016-2020 are analyzed. The task of improving the development of the territorial community, which should be implemented at the state and local levels, is highlighted. A mechanism for improving the development of local budgets has been proposed, which will make it possible to use local budget funds more rationally by strengthening the competitive advantages of the local community and intensifying investment activities. The directions of development of territorial communities for the medium term in Ukraine are singled out.

Key words: local budget, local self-government, territorial community, decentralization, subsidiarity, living standards, investment climate, economic development. 